\title{
The Research Based on the Concept of "CGCM" Employment Entrepreneurship about Reconstruction of Training System of Logistics Management Major
}

\author{
YunpingAi ${ }^{1}$, WeiZhao ${ }^{2, *}$ \\ ${ }^{1}$ School of International Business, AnhuiInternational Studies University, Hefei 231201, China, \\ ${ }^{2}$ Hefei Vocational College of Finance and Economics, Anhui, He fei 230601, China ) \\ *Correspondding Author.
}

\begin{abstract}
Professional training system of Employment entrepreneurship concept is a key link in the process of teaching, and the effect is directly related to the quality of the logistics personnel training. Combining with reconstruction of professional training system of "employment entrepreneurship" concept launched in School of International Business, Anhuilnternational Studies University, the paper probe into new ideas and new practices of reconstruction of training system of logistics management major from the following four aspects: Cultivate Employment and Entrepreneurship Ability, Guide Employment and Entrepreneurship Awareness, Create Employment and Entrepreneurship Environment, Mold Employment and Entrepreneurship Team.
\end{abstract}

Keywords: "CGCM" employment entrepreneurship,logistics management,reconstruction of system

\section{Introduction}

With the rapid development of China's logistics industry and the acceleration of the process of logistics technology, there are many logistics enterprises in the current market, which leads to more fierce competition among logistics enterprises and increasing demand for logistics talents. In order to improve students' practical work ability and enhance their employment competitiveness, the logistics management major of Anhui Foreign Studies University puts forward the idea of employment and entrepreneurship based on "CGCM", reconstructs the training system of logistics management major, improves the teaching effect, and then achieves the purpose of improving students' employment and entrepreneurship. The teaching reform through the adjustment of the talent training program, the reconstruction of the professional core curriculum content system, the tempering of the logistics skills competition, the optimization of the on-the-job internship program, and the continuous and subtle cultivation of entrepreneurial concepts to continuously improve the employment and entrepreneurship of students Ability to meet the industry's growing demand for high-level logistics talents.

\section{The Basic Connotation of "CGCM"}

"CGCM" is to cultivate employment and entrepreneurship ability, guide employment and entrepreneurship awareness, create employment and entrepreneurship environment. It is the abbreviation of the four words "mold employment and entrepreneurship team".At the same time, in order to achieve long-term and stable development, colleges and universities must constantly adjust the talent training programs of various majors to adapt to the changes in the demand for talents due to social development. Logistics management major is a logistics management talent who aims to master modern logistics management theory, means and methods of information system, and has strong practical operation ability such as logistics management, planning and design, in order to meet the needs of socialist market economy.

2.1 "C"-Cultivate the ability of employment and entrepreneurship

ISSN: 0010-8189

(C) CONVERTER 2021

www.converter-magazine.info 
Improve the special ability of employment and entrepreneurship. Employment and entrepreneurship is a process in which entrepreneurs use various entrepreneurial resources to achieve their entrepreneurial goals on the basis of identifying business opportunities. Therefore, a successful employment entrepreneur needs not only a clear awareness of employment and entrepreneurship and the support of excellent employment and entrepreneurship psychology, but also the ability to solve employment and entrepreneurship problems, that is, employment and entrepreneurship ability. Employment and entrepreneurship ability is a comprehensive ability with intelligence as the core and creative characteristics. Through cultivation, students will be able to master the employment and entrepreneurship skills needed in actual entrepreneurship, continuously improve and improve their core competencies, and at the same time be able to grasp business opportunities, efficient management, good at communication, and achieve employment and entrepreneurship goals with unique leadership skills.

\section{2 "G" - Guiding the sense of employment and Entrepreneurship}

Establish the sense of employment and entrepreneurship. The awareness of employment and entrepreneurship includes employment and entrepreneurship needs, employment and entrepreneurship motivation, employment and entrepreneurship interest, employment and entrepreneurship ideal, employment and entrepreneurship confidence and employment and entrepreneurship world outlook. Through education and guidance, we can stimulate students' innovative thinking in employment, enhance their awareness of risk, honesty, business, responsibility and team, and guide them to change the concept of passive employment and entrepreneurship into that of active employment and entrepreneurship.

\section{3"C"-Create an environment for employment and entrepreneurship}

Grasp the procedures and methods of employment and entrepreneurship activities, and cultivate students' employment and entrepreneurship spirit and employment and entrepreneurship capabilities. Employment and entrepreneurship practice is a key link in employment and entrepreneurship education. This link can be divided into two types: situational simulation practice and post-post internship practice. In the course learning stage, the practice of situational simulation and entrepreneurship is the main part. "Logistics training situation simulation" and other situation simulation practice is under the guidance of teachers, through the practice simulation of logistics procurement, storage, distribution and other whole or part of the supply chain operation process, so that students can directly experience the essence of logistics operation management under the supply chain link, and cultivate students' Employment Entrepreneurship and employment entrepreneurial ability. In the internship stage, we should focus on creating employment and entrepreneurship environment. Among them, the internship is organized by the school to practice in related logistics enterprises, and the school teachers, technical experts and backbones of enterprises jointly serve as "mentors". On-the-job internship is signed by the school and relevant logistics enterprises, and on the basis of relevant training for students in the early stage, on-the-job internship is carried out in relevant logistics positions of enterprises. Through internships, students can have a more thorough understanding of professional skills and truly experience the employment and entrepreneurial environment, thereby ensuring that students can do their utmost to improve their professional skills before actually embarking on a job.

\section{4 "M"-Build employment and entrepreneurship team}

Cognitive team, cultivate the psychological quality of employment and entrepreneurship. Through this stage of learning and training, students can be familiar with the 5P elements of the team and the differences between the team and the group. Be able to master the principles, steps, composition and evolution of tree building entrepreneurial team. Through the cultivation at this stage, students can think, judge, choose and make decisions independently. The enterprising spirit of taking risks, fighting hard, taking responsibility and pioneering and innovating. Perseverance, tenacious efforts, dedication and good at unity and cooperation.

ISSN: 0010-8189

(C) CONVERTER 2021

www.converter-magazine.info 
III. The Overall Conception of the Logistics Management Professional Training System Reconstruction Based on the "CGCM" Employment and Entrepreneurship Concept

Through the joint implementation of the "CGCM" employment and entrepreneurship concept by teachers and students, the logistics management professional curriculum system will be reconstructed and reformed, the goal will be repositioned, and the students will form an effective teaching model during the implementation of the project to achieve the training of students the requirements of application capabilities. Finally, four "Realizations" are achieved, namely, the docking of talent training program and cultivation of employment and entrepreneurship. Realize the docking of curriculum content system and guiding employment and entrepreneurship consciousness. To explore and reform the mode of internship and create employment and entrepreneurial environment. Realize the docking of building skills competition team and building employment and entrepreneurship team.

\section{The Concrete Implementation Process of Reconstructing the Training System of Logistics Management Specialty Based on the Employment and Entrepreneurship Concept of "CGCM"}

\subsection{Re-adjust the professional talent training program (cultivate employment and entrepreneurship)}

Talent training program is the basis of teaching organization, the step of teaching accumulation, and the main standard of checking and evaluating school teaching activities. All teaching activities of a school must be based on the established talent training program of its major. At the same time, in order to achieve long-term and stable development, colleges and universities must constantly adjust the talent training programs of various majors to adapt to the changes in the demand for talents due to social development. Logistics management major is a logistics management talent who aims to master modern logistics management theory, means and methods of information system, and has strong practical operation ability such as logistics management, planning and design, in order to meet the needs of socialist market economy. There may be many factors involved in cultivating students' core entrepreneurial competence, but from the perspective of college teaching, we must start with the adjustment of professional talent training programs. First, there must be specialized employment and entrepreneurship-related courses in the talent training program; second, the teaching hours of each course must be adjusted as needed, and the teaching order of each course can be appropriately changed as needed. Finally, the content of national and provincial skills competition runs through the teaching of each course of the talent training program. In order to improve the theoretical and practical level of students' employment and entrepreneurship, enhance the employment competitiveness, and finally meet the growing demand of logistics industry for high-level logistics talents.

\subsection{Reorganize the content system of the course (to guide employment and entrepreneurship awareness)}

Carrying out employment and entrepreneurship education for college students and improving their employment and entrepreneurship capabilities are an important part of quality education and an important way to cultivate innovative talents with innovative spirit and creative ability. The report of the 19th National Congress of the Communist Party of China put forward the development strategy of "adhere to the path of independent innovation with Chinese characteristics." As one of the important ways to achieve the goal of employment and entrepreneurship education, employment and entrepreneurship course aims to popularize employment and entrepreneurship knowledge, cultivate college students' innovation consciousness and entrepreneurship, and improve their entrepreneurial practice ability. As an open education, entrepreneurship curriculum is characterized by comprehensiveness and practicality, integrating school education and social education, and integrating curriculum education and practical education. In order to better promote the career development of college graduates and enhance the entrepreneurial employment ability of college students majoring in logistics management, on the one hand, special employment and entrepreneurship courses are required in the course content system. On the other hand, "employment and entrepreneurship factors" are added to the courses of logistics management, especially the core courses of the major (for example: the storage and distribution of materials under the conditions of "Internet $+"$ ). In addition, we need to further sort out the knowledge points of each professional course to avoid repetition and omission. In order to

ISSN: 0010-8189

(C) CONVERTER 2021

www.converter-magazine.info 
effectively promote the construction of logistics professional courses, cultivate students' awareness of employment and entrepreneurship, and improve their ability of employment and entrepreneurship.

4.3 Explore the reform and internship mode (create employment and entrepreneurship environment)

Internship (including on-the-job internship and on-the-job internship), as its name implies, is practice and learning, learning while practicing. It mainly refers to the practical study arranged by the school or chosen by the students to work in the field after they have mastered the basic professional theoretical knowledge. This link has become an important part of school education, and it is also an important prelude for students to connect with the social market. During the school period, students generally learn professional theoretical knowledge with zero foundation. Few majors can truly combine practice to carry out professional learning. The depth of employment and entrepreneurship courses and employment skills training is far from reaching the level of employment. Therefore, in order to prevent students from being in a state of "talking on paper" in their professional studies, professional internships must be regarded as an integral part of teaching, and a strict organizational model must be formed. For this reason, as a student of logistics major, his internship can be divided into two parts: following post and replacing post. Among them, the internship can be carried out in the form of "apprenticeship" according to the needs. The internship is organized by the school to the relevant logistics enterprises, and the school teachers and enterprise technical experts and backbones jointly act as "mentors". On-the-job internship is signed by the school and relevant logistics enterprises, and on the basis of relevant training for students in the early stage, on-the-job internship is carried out in relevant logistics positions of enterprises. Through practice, students can understand their professional skills more thoroughly, understand the importance of "learning to be useful", apply the professional knowledge learned by schools to practice, and experience the employment and entrepreneurship environment in the process of practice. It can make students gradually realize the insufficiency of their own scientific and theoretical level, and can make up for their own shortcomings while studying, so as to ensure that students can do their best to improve their professional skills before they actually embark on the job. Of course, in the teaching stage, the employment and entrepreneurship practice should be based on the situation simulation practice of training and other links. Under the guidance of teachers, mainly through the "logistics training situation simulation" and other ways, simulate the whole or part of the logistics procurement, storage, distribution and other supply chain operation process, so that students can directly experience the essence of logistics operation management under the supply chain link, and cultivate students' employment and Entrepreneurship.

\subsection{Focus on building a skill competition team (building an employment and entrepreneurship team)}

The orientation of training students in vocational colleges is very clear. It trains professional and technical talents in the front line of production to serve the social and economic construction and development. The working goal is to complete every task with high quality and efficiency, and to have corresponding comprehensive qualities. Skills competition has guiding significance in guiding students' professional quality. The communication skills, teamwork skills, corporate management concepts and innovative spirit required for professional quality are fully reflected in the competition projects. Only when the teams cooperate with each other and are skilled in professional skills can they do their work and complete tasks.

Students' sense of professional competition can be fully expressed in the competition. Good competition results are guaranteed by solid training, high comprehensive quality and psychological quality. Students participating in the competition experience that details determine success or failure. The results are affected by professional knowledge, skills, comprehensive ability and psychological quality. If you can't make too many mistakes in the competition, you should control and grasp the rhythm of the competition, not be influenced by the outside world, and give up easily until the last minute, and let the students form a tenacious fighting spirit and a sense of competition. The construction of professional courses and entrepreneurship and employment courses in vocational colleges also has many connotations of connecting with the society. As long as the students selected through skill competitions at all levels are first-line high-skilled professionals required by relevant enterprises at all levels in society, the quality of entrepreneurship and employment is very high. For this reason, as a logistics student, you should make full use of the

ISSN: 0010-8189

(C) CONVERTER 2021 
good conditions provided by the college. On the one hand, actively participate in the annual skill competition organized by the college, and constantly consolidate your logistics skills through skill training and competitions. On the other hand, through the relevant logistics software, actively carry out inter school and inter provincial online skills competition to earn "skills points", and select excellent skills players to participate in the provincial logistics class B and national logistics class a skills competition in combination with the school level annual skills competition. And strive to achieve good results in the skill competition. Teachers should also set good examples for students who have achieved good results in the skill competition, and guide other students to master professional knowledge and cultivate their own abilities, so as to enter the society, serve enterprises and achieve "zero distance" posts after graduation.

\section{Conclusions}

This article takes the idea of improving employment and entrepreneurship as the main line, and focuses on exploring new ideas and new ideas for the reconstruction of the logistics management professional training system from four aspects: cultivating employment and entrepreneurship capabilities, guiding employment and entrepreneurship awareness, creating employment and entrepreneurship environments, and building employment and entrepreneurship teams practice. Over the past few years, in the process of talent cultivation, the research group has found that students are more interested in learning, gain a lot, have better cultivation effect and high student evaluation, and finally achieve the students' employment and entrepreneurship ability after graduation, which has been greatly improved. The research ideas and methods of the subject have strong practical effect and promotion value.

\section{Acknowledgments}

The research team project of Anhui International Studies University in 2019-the research team of rural logistics system optimization No.: awkytd1904

\section{References}

[1]. R.J. Fang, “On the construction of innovation and entrepreneurship education system in colleges and universities," Journal of Changzhou Institute of Technology (Social Science Edition), no.3, 2011.

[2]. R. Heng, "Research and Exploration on the Training of Applied Talents in Logistics Management Major," Theoretical Research on Urban Construction (Electronic Edition), no. 11, 2013.

[3]. W.T. Zhu, "Research and practice of simulation company teaching mode in logistics comprehensive training courses," Logistics Engineering and Management, vol. 35,no. 3, pp. 208-211, 2013. 